\title{
TRENDS AND PREDICTION OF PANDEMIC COVID-19 SITUATION IN UTTAR PRADESH, INDIA
}

\author{
Suraj kumar*1 \\ ${ }^{1} . \mathrm{PhD}$., \\ Associate Professor \& Head, \\ Dept. of Physiotherapy, \\ Faculty of Paramedical sciences, \\ Uttar Pradesh University of Medical Sciences, \\ Saifai, Etawah, U.P, India.

\section{Gowrishankar Potturi ${ }^{3}$ \\ ${ }^{3} \mathrm{PhD}$., \\ Lecturer,} \\ Department of Physiotherapy, \\ Faculty of Paramedical Sciences, \\ Uttar Pradesh University of Medical Sciences, \\ Saifai, Etawah, \\ U.P, India.
}

\author{
Arushi Kumar ${ }^{2}$ \\ ${ }^{2}$.Medical Researcher, \\ A/82, Omex City, \\ Lucknow, \\ Uttar Pradesh, \\ India.
}

SOURCE OF FUNDING: NIL

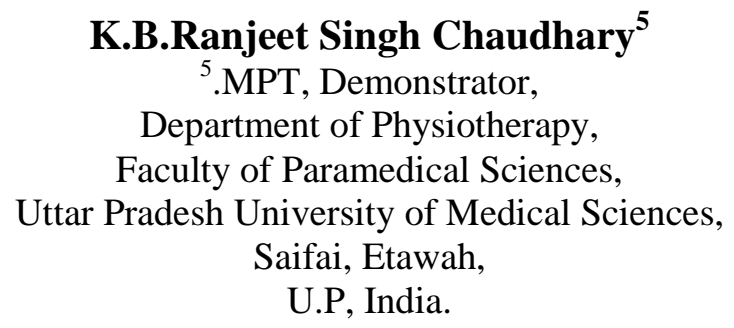

CONFLICTS OF INTEREST: The authors declare no conflicts of Interest

AUTHORS CONTRIBUTION:

Suraj kumar - concept, experimental studies, manuscript preparation, Guarantor

Arushi Kumar-definition of intellectual content, clinical studies

Gowrishankar Potturi - literature search, data analysis, statistical analysis, manuscript review

Rajkumar - design, data acquisition, manuscript editing

K.B.Ranjeet Singh Chaudhary - literature search, data acquisition, manuscript review

ACKNOWLEDGEMENT

The authors acknowledge the authorities of Uttar Pradesh University of Medical Sciences, Saifai, Etawah, Uttar Pradesh for approval and encouragement

Article DOI: $\underline{\text { https://doi.org/10.36713/epra4603 }}$

\section{SUMMARY}

COVID-19 is a disease caused by coronavirus that was first identified in Wuhan, China and was declared pandemic. Uttar Pradesh is one of the largest Indian states which is highly populous. There were 81999 confirmed cases in India as on 15th May, 2020 of which 3902 from Uttar Pradesh. Data of confirmed cases, recoveries and death trolls were collected from Ministry of Health and Family welfare and other reliable website. There is 53.1\% recovery rate in the COVID-19 cases in Uttar Pradesh. A good health infra-structure, planning, high immunity in population, adequate isolation/ quarantine facilities, confrontational testing has increased recovery rates. Institutes like UPUMS are providing Ayurvedic preparation Raj Nirwan Ras (RNR) and nutritious diet along with breathing exercises showing high recovery rates. This type of treatment model could be implemented in other hospitals for a good and faster recovery rate. The prediction of transmission rate in next 30 days in Uttar Pradesh is not feasible as the number of migrant workers influx, people attending religious congregation, citizens not following lock down properly, and rapid testing could increase the number of confirmed cases.

KEYWORDS: Uttar Pradesh, COVID-19, Raj Nirwan Ras, Recovery rate 


\section{INTRODUCTION}

COVID-19 is a disease caused by coronavirus that was first identified in Wuhan, China ${ }^{1}$. It belongs to the Coranaviridae family in the Nidovirales order; the subgroups of corona virus' family are alpha, beta, gamma and delta corona virus ${ }^{2}$. The SARS-CoV, H5N1 influenza, H1N1 2009 are some of the important infectious respiratory illnesses caused by these viruses. The World Health Organization (WHO) has declared the COVID-19 as a health emergency and pandemic ${ }^{3}$.

India is a subcontinent of ASIA, having a population of 1,387,297,452 people, 28 states and 8 union territories ${ }^{4}$. Uttar Pradesh is one of the Indian states which is highly populous with a population of 22,49,79,000 (based on 2019 population projection by NCP report) people ${ }^{5}$. The first case in India was reported on 30-01-2020 and in Uttar Pradesh on 5-032020 , originated from Iran at Ghaziabad 7 . There were 81999 confirmed cases in India as on 15th May, 2020. Uttar Pradesh had a total of 3902 confirmed cases as on 15th May, 2020.

Through this study we shall try to find out the trends of death rate, rate of transmission and the recovery rates in Uttar Pradesh in comparison with Nation as a whole with an emphasis on prediction of transmission in Uttar Pradesh.

\section{METHODS}

We noted daily data of confirmed, deaths and recoveries from $17^{\text {th }}$ April to $15^{\text {th }}$ May 2020 of Uttar Pradesh and India. Data of Levels of Hospitals and Isolation beds strength of Uttar Pradesh was collected. Various published papers were reviewed on COVID-19 in India. Data from Ministry of Health and Family welfare website of India and Uttar Pradesh were also collected. Data about the causes of death, methods of transmission and preventive measures from various reliable websites were also analyzed.

\section{RESULTS}

Uttar Pradesh is an Indian state with a population of density of 828 persons per sq.km. It has a total of 75 districts with Lucknow as its capital. The isolation hospital bed facilities in Uttar Pradesh are Level $1-3215$ beds, Level-2-15837beds, Level 3-12090 beds. The total number of isolation beds including L1, L2, L3 and L1 covid care centres is $53459^{8}$. The total number of confirmed cases as on 15th May, 2020 is 3902 , number of recoveries 2072, number of deaths 88 . According to state health department data, $49.5 \%$ COVID-19 cases in Uttar Pradesh are in 21-40 age group, while $25.6 \%$ are in $41-60$ age group.

As on May 15th, 2020, the numbers of confirmed cases in India were 81,999 in which 3902 were from Uttar Pradesh. The state contributes $4.75 \%$ of the total cases in India. The trend of infected people from 17th April, 2020 to 15th May 2020 (Fig. 1 See Appendix). The death of the people in Uttar Pradesh by this virus (Fig. 2 See Appendix) was 88, that is $2.25 \%$ of the infected people. This death percentage is low when compared to the country death percentage $(3.22$ $\%)$. The recovery rate of the patients is very high in Uttar Pradesh which is $53.1 \%$ while the recovery rate in India is $34.1 \%$. (Fig. 3- See Appendix). The important events in the timeline of COVID-19 are narrated in Table -1.(See Appendix)

The maximum number of cases were reported in the districts of Agra, Meerut, Kanpur Nagar, Lucknow, Gautam Budha nagar. The minimum numbers of cases were reported in Lalitpur, Sonbhadra, Hamirpur, Kushinagar, Mahoba. The maximum recoveries were found in Agra, Lucknow, Kanpur nagar, Saharanpur, Gautam Budha nagar. The minimum recoveries were reported in Mau, Shahjahanpur, Ayodhya, Kanpur Dehat, Balrampur ${ }^{9}$.

\section{DISCUSSION}

In Uttar Pradesh, the COVID-19 services were provided by structuring the hospitals into Level-1, Level-2, Level-3 categories. There is more than 50\% recovery rate in the COVID-19 cases in Uttar Pradesh. The state's recoveries have surpassed the number of active $\operatorname{cases}^{10}$. The robust health infra structure, robust planning, high immunity in population, adequate isolation/ quarantine facilities, confrontational testing could be the reasons for good recovery rate in Uttar Pradesh ${ }^{11}$. The high recovery rate and low death rate in the state can also be linked to the comorbidities among the aged population. The early lock down in Uttar Pradesh with strict surveillance measures also attribute the steady recovery rate, as the affected persons are quarantined disabling the infection chain ${ }^{12}$.

The recovery rate is high in the region of Agra can be attributed to the robust health planning provided in this region by Level-3 hospitals. One of the Level -3 hospitals, Uttar Pradesh University of Medical Sciences has shown records in the recovery rate. Almost 71 cases including a child of 9 months referred from Agra were recovered with full health and were discharged with negative COVID-19 results. Proper quarantine facilities, Sanitation, Advanced Biomedical waste Management, sophisticated Medical services, training of health care workers about the donning and doffing, infection control, ventilator management were few reasons for high recovery rates in UPUMS. The doctors at UPUMS are giving Ayurvedic preparation RNR and breathing exercise to the COVID19-cases along with good and balanced nutrition also contributed to the fast 
and early recoveries. The other Level-3 hospitals in Uttar Pradesh also showed robust results in recoveries like GVSM, SGPGI, KGMU, medical colleges and others because of good state planning and rules passed by the government from time to time.

The prediction of any infectious disease can be done by SIR model (Susceptibility, Infection, recovery), Exponential Model, Logistic model, Susceptible infectious Susceptible (SIS) model ${ }^{13}$. In a published paper, it was predicted that the cumulative confirmed cases could be around 1800 by May 30, $2020^{14}$, However, the prediction was inappropriate as the number of confirmed cases were 3902 by $15^{\text {th }}$ May itself. So it is evident that prediction of confirmed cases in near future in Uttar Pradesh may not be appropriate. The reasons being the state had a huge influx of around 13.5 lakh migrant workers during the Lock down period $^{15}$. The testing of asymptomatic people has increased the number of cases as a part of ICMR project in Agra and Lucknow which could also reveal the hidden cases leading to rise in number of confirmed cases $^{16}$.

\section{CONCLUSION}

The number of recoveries is highest in Uttar Pradesh in comparison with India as a whole. The Robust health planning and optimization of health infrastructure, high immunity in population, adequate isolation/ quarantine facilities, confrontational testing, early lock down could be the reasons for the high recovery rate despite having high density population. Institutes like UPUMS are providing Ayurvedic preparation Raj Nirwan Ras (RNR) and nutritious diet along with breathing exercises showed high recovery rates. This type of treatment model could be implemented in other hospitals for a good and faster recovery rate. The prediction of transmission rate in Uttar Pradesh is not feasible as the number of migrant workers influx, members' attending from religious congregation, and their close approximates and rapid testing could increase the number of confirmed cases.

\section{REFERENCES}

1. N. Zhong, B. Zheng, Y. Li, L. Poon, Z. Xie, K. Chan, et al. Epidemiology and cause of severe acute respiratory syndrome (SARS) in Guangdong, People's Republic of China, in February, 2003.

2. Fehr AR, Perlman S. Coronaviruses: an overview of their replication and pathogenesis. Methods Mol Biol. 2015;1282:1-23.
3. Organization WH. Laboratory testing for coronavirus disease 2019 (COVID-19) in suspected human cases: interim guidance, 2 March 2020. World Health Organization, 2020.

4. The Essential Desk Reference, Oxford University Press, 2002, p. 76, ISBN 978-0-19-512873-4 "Official name: Republic of India."

5. Kopf, Dan; Varathan, Preeti (11 October 2017). "If Uttar Pradesh were a country". Quartz India. Retrieved 20 May 2019.

6. "Home | Ministry of Health and Family Welfare | GOI". mohfw.gov.in. Retrieved 17 May 2020.

7. "Coronavirus update: New case reported from Ghaziabad, India now has 30 patients". Livemint. 5 March 2020.

8. DIRECTORATE OF MEDICAL \& HEALTH SERVICES, www.dgmhup.gov.in (online), http://dgmhup.gov.in/en/default, retrieved on 15, May, 2020.

9. LIVEMINT, www.livemint.com (Online), 14th May, 2020, https://www.livemint.com/news/india/65-newcoronavirus-cases-reported-in-up-as-of-8-00-am-may14-11589426656062.html, viewed on 18-05-2020.

10. THE NEW INDIAN EXPRESS, newindianexpress.com (online), $\quad 15^{\text {th }} \quad$ May, 2020, https://www.newindianexpress.com/nation/2020/may/15/ 51-corona-patients-cured-in-up-states-recovery-ratehighest-among-most-infected-provinces-2143793.html, viewed on $17^{\text {th }}$ May, 2020

11. LIVE MINT, livemint.com(online), 24 April, 2020, https://www.livemint.com/news/india/why-some-statesdo-better-than-others-in-the-covid-19-fight11587732917794.html, viewed on $17^{\text {th }}$ May, 2020.

12. TIMES OF INDIA, times of india.indiatimes.com (online), $\quad 15^{\text {th }} \quad$ May 2020, https://timesofindia.indiatimes.com/city/lucknow/50patients-in-21-40-age-group-keep-up-covid-recoveryrate-high/articleshow/75747802.cms, viewed on $17^{\text {th }}$ May, 2020.

13. D. Osthus, K.S. Hickmann, P.C. Caragea, D. Higdon, S.Y.D. Valle, Forecasting seasonal influenza with a state-space SIR model, Ann. Appl. Stat. 11 (2017) 202224. https://doi.org/10.1214/16-AOAS1000.

14. palsh Ghosh, Rik Ghosh, Bibhas Chakraborty.COVID19 in India: State -Wise Analysis and Prediction, medRxiv 2020.04.24.20077792.

15. THE NEW INDIAN EXPRESS. www. newindianexpress.com.(online) 15th May, 2020, https://www.newindianexpress.com/nation/2020/may/15/ over-135-lakh-migrant-workers-reach-uttar-pradeshtill-date-officials-2143796.html, viewed on 17th May, 2020.

16. Ch. Himani; na (13 April 2020). "ICMR advises 'pool testing' in low-infection areas to increase number of Covid-19 tests". ThePrint. Retrieved 15th May, 2020. 
ISSN (Online): 2455-3662

EPRA International Journal of Multidisciplinary Research (IJMR) - Peer Reviewed Journal Volume: 6 | Issue: 6 | June 2020 || Journal DOI: 10.36713/epra2013 || SJIF Impact Factor: 7.032 ||ISI Value: 1.188

\begin{tabular}{|l} 
APPENDIX \\
\begin{tabular}{|l|l|}
\hline \multicolumn{1}{|c|}{ TABLE 1 : TIME LINE OF COVID-19 IN UTTAR PRADESH } \\
\hline DATE & INCIDENT \\
\hline $05-03-2020$ & First case reported in Ghaziabad, originated from Iran \\
\hline $17-03-2020$ & $\begin{array}{l}\text { Closure of all educational institutes, cinemas, shopping malls, swimming pool, gyms, } \\
\text { multiplexes and tourist attractions }\end{array}$ \\
\hline $22-03-2020$ & The state government announced lock down in 15 districts of the state \\
\hline $01-04-2020$ & First death reported in Basti. \\
\hline $03-04-2020$ & $\begin{array}{l}59 \text { cases reported on a single day originating from a religious congregation in } \\
\text { Nizammuddin. }\end{array}$ \\
\hline $05-04-2020$ & Around 65,000 workers were brought back to the state \\
\hline
\end{tabular} \\
\hline
\end{tabular}

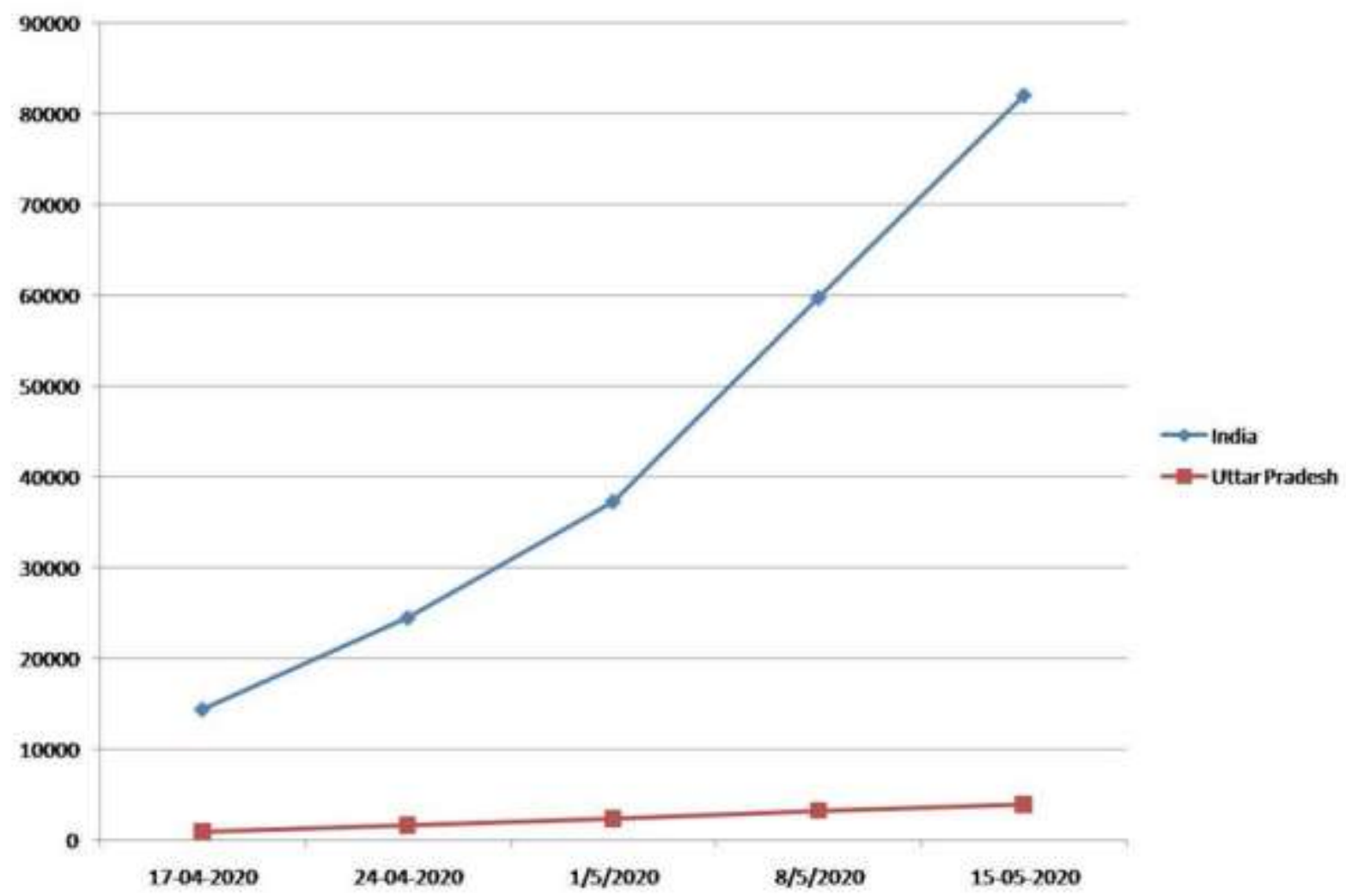

Fig 1 : Number of Cases in Uttar Pradesh in comparison with India as a whole 
ISSN (Online): 2455-3662

EPRA International Journal of Multidisciplinary Research (IJMR) - Peer Reviewed Journal Volume: 6 | Issue: 6 | June 2020 || Journal DOI: 10.36713/epra2013 || SJIF Impact Factor: 7.032 ||ISI Value: 1.188

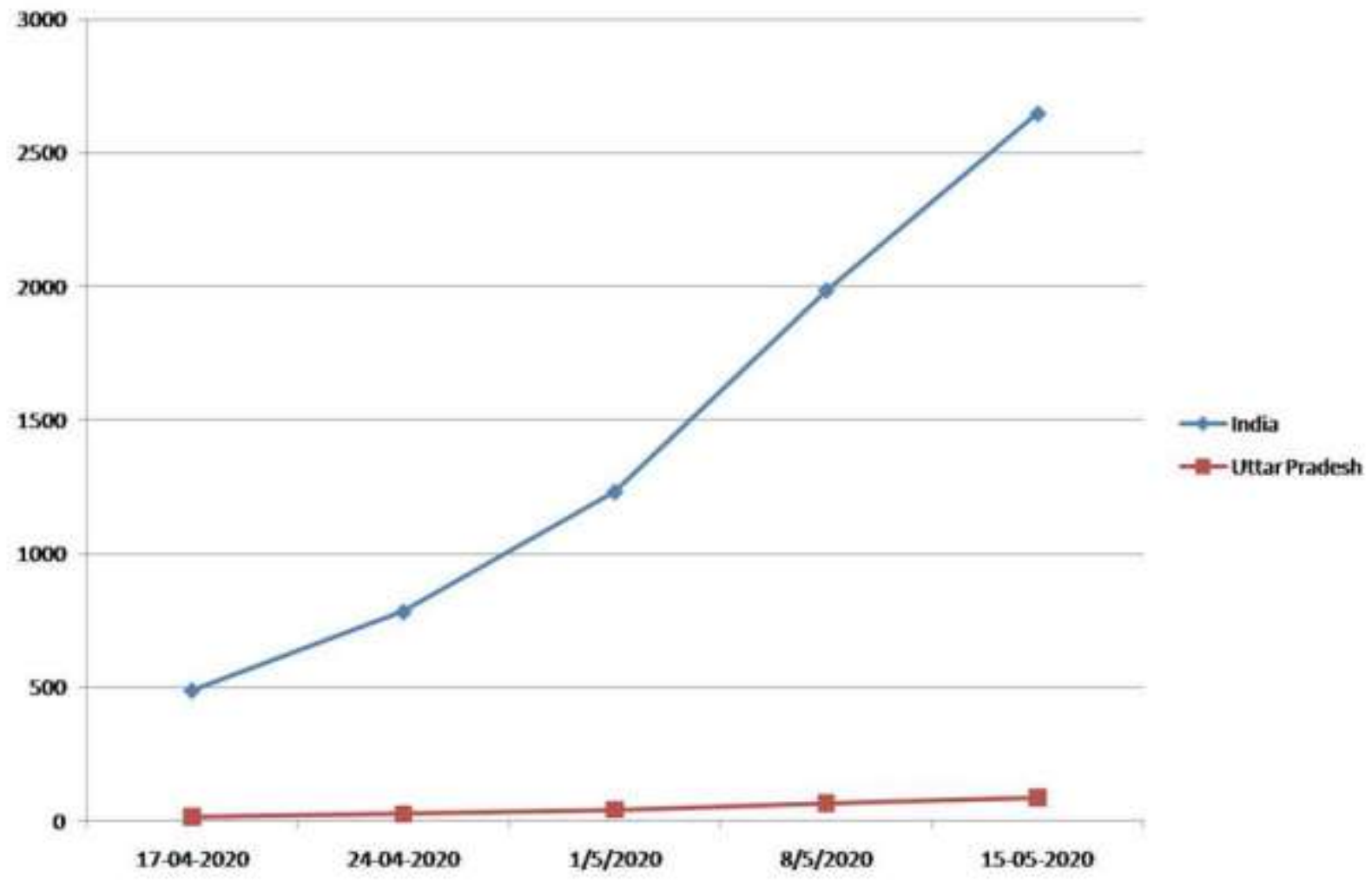

Fig 2 : Number of Deaths in Uttar Pradesh in comparison with India as a whole 
ISSN (Online): 2455-3662

EPRA International Journal of Multidisciplinary Research (IJMR) - Peer Reviewed Journal Volume: 6 | Issue: 6 | June 2020 || Journal DOI: 10.36713/epra2013 || SJIF Impact Factor: 7.032 ||ISI Value: 1.188

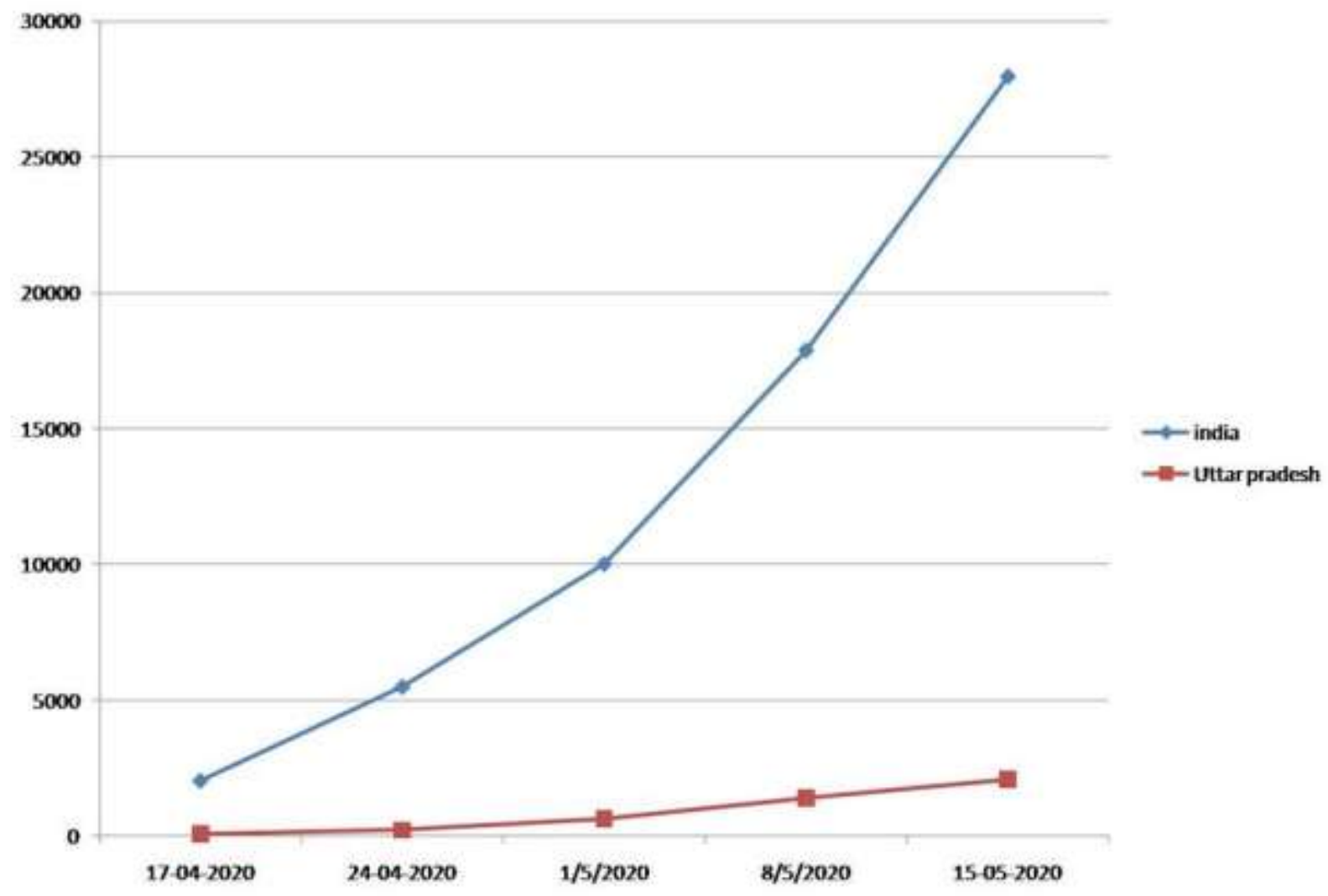

Fig 3 : Number of Recoveries in Uttar Pradesh in comparison with India as a whole 